\title{
Comparative characteristics of anthropometric indicators, level of physical and technical readiness of young players of 12 and 15 years of different playing fields
}

\author{
Kozina Z.L. ${ }^{1}$, Leemans A. ${ }^{2}$, Marino J. ${ }^{3}$, Cruz J. ${ }^{3}$, Golenkov A.A. ${ }^{1}$, Dubich V.V. ${ }^{1}$ \\ ${ }^{1}$ Department of Olympic and Professional Sport and Sport Games, H.S. Skovoroda Kharkiv \\ National Pedagogical University, Ukraine \\ ${ }^{2}$ University Medical Center Utrecht, the Netherlands \\ ${ }^{3}$ University del Chubut, Argentina
}

DOI: https://doi.org/10.34142/HSR.2019.05.02.05

\begin{abstract}
Purpose: To develop model characteristics of physical and technical fitness of players of 12 and 15 years of different playing roles. Material and methods. The study was attended by football players of 12 and 15 years of sport school "Areal" Kharkiv, in which the developed technologies were applied in the educational process. In total, 23 forvards, 28 midfielders, 30 defenders and 15 goalkeepers were invited for the survey. Indicators of the running time of segments of $15 \mathrm{~m}$ from the course, $30 \mathrm{~m}$ from the course and $60 \mathrm{~m}$ from the course were determined; shuttle running time 5 to $20 \mathrm{~m}$. Determined the length and weight of the body; Heart rate at rest and heart rate after a shuttle run. From the technical readiness indicators were determined: the time of holding the soccer ball on the foot; juggling, that is, the number of shots of the ball with the foot without losing the ball; time to run a soccer ball on a mission; goal kicks for accuracy; strikes the ball at flight range.

Results. Young players of 12 and 15 years of different game specializations differ in terms of physical and technical fitness. The largest number of significant differences were found in the technical readiness of football players for 15 years. Field players at speed capabilities are significantly superior to goalkeepers. Goalkeepers, on the contrary, have lower running speeds. The level of speed endurance is relatively high for defenders and midfielders, as opposed to goalkeepers. The obtained data allowed us to build models of physical development, physical and technical readiness of players of 12 and 15 years of different playing fields, on the basis of which training programs for representatives of different playing roles can be developed.

Conclusions. The data obtained indicate the need for a differentiated approach in the training process of young football players, taking into account their playing role. The differentiated approach is more relevant at the age of 15 compared to the age of 12 .
\end{abstract} Keywords: football; game play; physical fitness; technical readiness; anthropometric indicators

Анотація

Козіна Ж.Л., Ліманс А., Маріно Ю., Круз Х., Голенков А.А., Дубич В.В. Порівняльна характеристика антропометричних показників, рівня фізичної та технічної підготовленості юних футболістів 12 та 15 років різних ігрових амплуа

Мета: розробити модельні характеристики фізичної та технічної підготовленості футболістів 12 та 15 років різних ігрових амплуа. Матеріал і методи. У дослідженні узяли участь футболісти 12 та15 років ДЮСШ «Ареал» м. Харкова, в навчально-тренувальному процесі яких застосовувалися розроблені технології. Всього для обстеження було запрошено 23 нападаючих, 28 півзахисників, 30 захисників і 15 воротарів. Визначалися показники часу пробігання відрізків 15 м з ходу, 30 м з ходу та 60 м з ходу; час човникового бігу 5 по 20 м. Визначали довжину та масу тіла; ЧСС спокою та ЧСС після човникового бігу. 3 показників технічної підготовленості визначали: час тримання футбольного м'ча на стопі; жонглювання, тобто кількість набивань м'яча стопою без втрати м'яча; час виконання ведення футбольного м'яча за завданням; удари по воротам на точність влучення; удари м'яча на дальність польоту.

Результати. Юні футболісти 12 і 15 років різних ігрових спеціалізацій розрізняються між собою за показниками фізичної технічної підготовленості. Найбільша кількість достовірних відмінностей виявлена у показниках технічної підготовленості футболістів 15 років.

Польові гравці по швидкісних можливостях істотно перевершують воротарів. Воротарі, навпаки, мають нижчі показники швидкості бігу. Рівень швидкісної витривалості відносно високий у захисників і напівпівзахисників на відміну від воротарів. Отримані дані дозволили побудувати моделі фізичного розвитку, фізичної та технічної підготовленості футболістів 12 та 15 років різних ігрових амплуа, на основі яких можуть бути розроблені програми тренувань для представників різних ігрових амплуа. Висновки. Отримані дані свідчать про необхідність діференційованого підходу в тренувальному процесі юних футболістів з урахуванням іх ігрового амплуа. Діференційований підхід набуває більшу актуальність у 15 років у порівнянні з віком 12 років. Ключові слова: футбол; ігрові амплуа; фізична підготовленість; технічна підготовленість; антропометричні показники

\section{Аннотация}

Аннотация

Козина Ж.Л., Лиманс А., Марино Ю., Круз Х., Голенков А.А., Дубич В.В. Сравнительная характеристика антропометрических показателей, уровня физической и технической подготовленности юных футболистов 12 и 15 лет разных игровых амплуа.

Цель: разработать модельные характеристики физической и технической подготовленности футболистов 12 и 15 лет разных игровых амплуа.

Материал и методы. В исследовании приняли участие футболисты 12 та15 лет ДЮСШ «Ареал» г.. Харькова, в учебнотренировочном процессе которых применялись разработаны технологии. Всего для обследования были приглашены 23 нападающих, 28 полузащитников, 30 защитников и 15 вратарей. Определялись показатели времени пробегания отрезков 15 м с ходу, 30 м с ходу и 60 м с хода; время челночного бега 5 по 20 м. Определяли длину и массу тела чсс покоя и чсС после челночного бега. Из показателей технической подготовленности определяли: время содержания футбольного мяча на стопе; жонглирование, то есть количество набивок мяча стопой без потери мяча; время выполнения ведения футбольного мяча по заданию; удары по воротам на точность попадания; удары мяча на дальность полета.

Результаты. Юные футболисты 12 и 15 лет разных игровых специализаций различаются между собой по показателям физической и технической подготовленности. Наибольшее количество достоверных различий обнаружено в показателях технической подготовленности футболистов 15 лет.

Полевые игроки по скоростным возможностям существенно превосходят вратарей. Вратари, наоборот, имеют более низкие показатели скорости бега. Уровень скоростной выносливости относительно высокий у защитников и полузащитников в отличие от вратарей.

Выводы. Полученные данные свидетельствуют о необходимости дифференцированных устных подхода в тренировочном процессе юных футболистов с учетом их игрового амплуа. Дифференцированных устных подход приобретает большую актуальность в 15 лет по сравнению с возрастом 12 лет.

Ключевые слова: футбол; игровые амплуа; физическая подготовленность; техническая подготовленность; антропометрические показатели 


\section{Introduction}

The problem of training young football players is becoming more urgent nowadays $[1,2,3]$. Effective functioning of the system of sports reserve, improving the quality of training and training process for young athletes can be ensured only with rigorous scientific substantiation of both the system as a whole and its individual components $[4,5,6]$. Optimal design of the training process technology, the formation of training programs, the selection of adequate training methods and methods of purposeful recovery and purposeful recovery is possible only on the basis of the laws of age-related development of information on the functional features of athletes $[7,8,9]$.

In the literature, aspects of this problem are fragmented $[10,11,12]$ and mainly concern skilled adult football players. At the same time, special attention should be paid to managing the development of adaptation, functional readiness, optimization of the training process of young footballers at the stage of advanced specialization. This is due to the fact that this stage of long-term sports training coincides with powerful ontogenetic processes, the beginning of the manifestation of individual features of the mechanisms of regulation of functions and adaptation processes, on the basis of which, in particular, the game specialization of young football players is determined [13, 14, 15].

Improving the efficiency of the training process is associated with the development and implementation of various means and methods of training athletes. One of the most effective approaches to optimize the training process, taking into account trends in the development of a particular sport, is the use of readiness indicators that allow you to individualize the training process [1].

But there is practically no information in the literary data regarding the model characteristics of the readiness of players of 12 and 15 years of different playing fields. The future of sports, including football, in the individualization of the training process $[4,5]$. Football is also a unique feature of combining in one team as players with different anthropometric and functional indicators. Of course, the construction of the training process is greatly complicated by the need to study and apply an individual approach to each player of the team, but it is a basic requirement of modern sports.

Individual approach is needed not only for players of different roles, but also for players of the same game functions. Modern scientific methods allow to give an accurate description of the individual characteristics of athletes and to build "ideal" models of athletes. However, such methods are rarely used, from which the effectiveness of the training process is significantly reduced.

Individual approach to the players is necessary at all stages of sports training, including at 12 and 15 years, since in these age groups there is a qualitative leap in the level of physical development, which is reflected in the indicators of physical and technical fitness [16, 17, 18]. In basketball, during this period there is a more rigorous distribution of athletes in terms of functions (which are not always clearly defined in athletes at this stage of preparation), their individual playing profile is determined, and therefore this period plays an important role in becoming a high-class athlete [19, $20,21]$. That is why the pressing issue is to determine the features of physical development, physical and technical preparedness of players of different game roles in these age groups.

Based on the above, this study hypothesized that at the age of 12 years there can already be significant differences in the indicators of physical development, physical and technical fitness, which become more significant at the age of 15 years.

The purpose of the study is to develop model characteristics of physical and technical fitness of players of 12 and 15 years of different playing fields.

\section{Material and methods}

\section{Participants}

The study was attended by football players of 12 and 15 years of school "Areal" Kharkiv, in which the developed technologies were applied in the educational process. A total of 23 forwards (12 players 12 years and 11 players 15 years), 28 midfielders (14 players 12 years and 14 players 15 years), 30 (15 players 12 years and 15 players 15 years), defenders and 15 goalkeepers were invited for the survey ( 8 players 12 years and 7 players 15 years).

\section{Experimental protocol}

To achieve this goal, a comprehensive testing of physical performance and basic indicators of functional fitness in young players of 12 and 15 years of different playing roles was carried out. In the course of the researches the indicators of speed qualities were determined by the time of running of segments of $15 \mathrm{~m}$ from the course, $30 \mathrm{~m}$ from the course and $60 \mathrm{~m}$ from the course (the test participant makes a run up to 10 meters, at the maximum speed crosses the starting line and overcomes the distance of 15 meters, $30 \mathrm{~m}, 60 \mathrm{~m}$ ); high speed endurance (shuttle running time 5 to $20 \mathrm{~m}$ ). 
From indicators of physical development the length and weight of the body were determined; from indicators of functional readiness - resting heart rate and heart rate after shuttle running.

From the indicators of technical readiness determined the following:

- time to hold the soccer ball on the foot: the test participant locks the ball on the foot and holds it for as long as possible. It is impossible to stuff and jump on a support leg;

- juggling, that is, the number of shots of the ball with the foot without losing the ball;

- the time of running a soccer ball on a mission. There is a ball on the line. From the line there are three skittles, a distance of $3 \mathrm{~m}, 6 \mathrm{~m}, 9.5 \mathrm{~m}$. According to the examiner's whistle, the test participant runs the skittles "snake" on the right side;

- shots on goal for accuracy of hit. The gates are divided into 6 equal squares. We set the ball at $11 \mathrm{~m}$. The task of the test participant is to get the ball into these squares, at the bottom - at most one touch of the ball to the ground, three balls per square. Number of hits - 18. One hit - 1 point.

- Ball strikes on flight range. Set the ball on the line. The test taker's job is to hit the ball as far as possible. The result is recorded at the first touch of the ball to the ground.

\section{Statistical analysis}

In the mathematical processing of primary materials of this study, in addition to the calculation of primary statistics, a comparative analysis of the averages by $\mathrm{t}$ - Student's $\mathrm{t}$ test was conducted. Indicators were processed using modern computer programs - EXEL and SPSS.

\section{Results}

Comparing the indicators of physical development (length and body weight) (Tables 1,2), it can be seen that according to these parameters the players of different game roles practically do not differ from each other $(p>0.05)$. This provision applies to both 12-year-olds and 15-year-olds. The average length of goalkeepers 12 years is $157.67 \mathrm{~cm}$, of defenders 12 years is $152.0 \mathrm{~cm}$, of midfielders 12 years is $155.6 \mathrm{~cm}$, of forwards 12 years is $155.6 \mathrm{~cm}$ The average values of the length of goalkeepers 15 years is $166.33 \mathrm{~cm}$, of defenders 15 years is 172.75 $\mathrm{cm}$, of midfielders 15 years is $168.2 \mathrm{~cm}$, of forwards 15 years is $170.8 \mathrm{~cm}$.

Indicators of physical development, physical and technical readiness of football players of 12 years of different playing fields (goalkeepers, $\mathrm{n}=8$, defenders, $\mathrm{n}=15$, midfielders, $\mathrm{n}=14$, forwards, $\mathrm{n}=12$ )

\begin{tabular}{|c|c|c|c|c|c|c|c|c|}
\hline \multirow{2}{*}{$\begin{array}{c}\text { Indexes } \\
1\end{array}$} & \multicolumn{2}{|r|}{ Playing fields } & \multirow{2}{*}{$\begin{array}{c}\bar{x} \\
4\end{array}$} & \multirow{2}{*}{$\begin{array}{l}S \\
5\end{array}$} & \multirow{2}{*}{$\frac{m}{6}$} & \multicolumn{2}{|c|}{$\mathrm{t}$} & \multirow{2}{*}{$\begin{array}{l}\mathrm{p} \\
9\end{array}$} \\
\hline & 2 & 3 & & & & 7 & 8 & \\
\hline \multirow{6}{*}{ Body length $(\mathrm{cm})$} & 1 & goalkeepers & 157.67 & 0.58 & 0.33 & $1-2$ & 1.74 & 0.14 \\
\hline & 2 & defenders & 157.67 & 0.58 & 0.33 & $1-3$ & 0.66 & 0.54 \\
\hline & 3 & midfielders & 155.60 & 5.27 & 2.36 & $1-4$ & 0.94 & 0.38 \\
\hline & 4 & forwards & 155.61 & 3.65 & 1.63 & $2-3$ & -1.00 & 0.35 \\
\hline & - & - & - & - & - & $2-4$ & -1.19 & 0.27 \\
\hline & - & - & - & - & - & $3-4$ & 0.00 & 1.00 \\
\hline \multirow{6}{*}{ Body weight (kg) } & 1 & goalkeepers & 43.67 & 1.15 & 0.67 & $1-2$ & 1.20 & 0.29 \\
\hline & 2 & defenders & 42.00 & 2.16 & 1.08 & $1-3$ & -0.05 & 0.96 \\
\hline & 3 & midfielders & 43.80 & 4.32 & 1.93 & $1-4$ & -0.38 & 0.72 \\
\hline & 4 & forwards & 44.60 & 4.04 & 1.81 & $2-3$ & -0.75 & 0.48 \\
\hline & - & - & - & - & - & $2-4$ & -1.15 & 0.29 \\
\hline & - & - & - & - & - & $3-4$ & -0.30 & 0.77 \\
\hline \multirow{6}{*}{$\begin{array}{l}\text { Heart rate rest } \\
\text { (beats } \cdot \mathrm{min}^{-1} \text { ) }\end{array}$} & 1 & воротарі & 76.00 & 3.46 & 2.00 & $1-2$ & -0.09 & 0.93 \\
\hline & 2 & захисники & 76.50 & 9.00 & 4.50 & $1-3$ & -0.05 & 0.96 \\
\hline & 3 & напівзахисники & 79.60 & 7.27 & 3.25 & $1-4$ & -2.04 & 0.09 \\
\hline & 4 & нападники & 82.80 & 5.02 & 2.24 & $2-3$ & -0.57 & 0.58 \\
\hline & - & - & - & - & - & $2-4$ & -1.34 & 0.22 \\
\hline & - & - & - & - & - & $3-4$ & -0.81 & 0.44 \\
\hline
\end{tabular}




\begin{tabular}{|c|c|c|c|c|c|c|c|c|}
\hline 1 & 2 & 3 & 4 & 5 & 6 & 7 & 8 & 9 \\
\hline \multirow{6}{*}{$\begin{array}{l}\text { Heart rate after a shuttle run } \\
\text { (beats } \cdot \mathrm{min}^{-1} \text { ) }\end{array}$} & 1 & goalkeepers & 178.00 & 3.46 & 2.00 & $1-2$ & 0.21 & 0.85 \\
\hline & 2 & defenders & 177.00 & 7.75 & 3.87 & $1-3$ & -0.79 & 0.46 \\
\hline & 3 & midfielders & 178.80 & 5.02 & 2.24 & $1-4$ & 0.87 & 0.42 \\
\hline & 4 & forwards & 174.00 & 7.35 & 3.29 & $2-3$ & -0.42 & 0.69 \\
\hline & - & - & - & - & - & $2-4$ & 0.60 & 0.57 \\
\hline & - & - & - & - & - & $3-4$ & 1.21 & 0.26 \\
\hline \multirow{6}{*}{ Shuttle Run (s) } & 1 & goalkeepers & 27.67 & 0.44 & 0.25 & $1-2$ & 0.85 & 0.43 \\
\hline & 2 & defenders & 27.35 & 0.51 & 0.26 & $1-3$ & -0.24 & 0.82 \\
\hline & 3 & midfielders & 27.46 & 0.11 & 0.05 & $1-4$ & 1.16 & 0.29 \\
\hline & 4 & forwards & 27.44 & 0.10 & 0.05 & $2-3$ & -0.46 & 0.66 \\
\hline & - & - & - & - & - & $2-4$ & -0.39 & 0.71 \\
\hline & - & - & - & - & - & $3-4$ & 0.27 & 0.80 \\
\hline \multirow{6}{*}{ Running 30 m (s) } & 1 & goalkeepers & 6.80 & 0.10 & 0.05 & $1-2$ & 1.88 & 0.12 \\
\hline & 2 & defenders & 6.49 & 0.26 & 0.13 & $1-3$ & 1.06 & 0.33 \\
\hline & 3 & midfielders & 6.53 & 0.21 & 0.10 & $1-4$ & 1.49 & 0.19 \\
\hline & 4 & forwards & 6.56 & 0.26 & 0.12 & $2-3$ & -0.25 & 0.81 \\
\hline & - & - & - & - & - & $2-4$ & -0.38 & 0.72 \\
\hline & - & - & - & - & - & $3-4$ & -0.17 & 0.87 \\
\hline \multirow{6}{*}{ Running 15 m (s) } & 1 & goalkeepers & 5.07 & 0.07 & 0.04 & $1-2$ & 3.52 & 0.02 \\
\hline & 2 & defenders & 4.73 & 0.15 & 0.08 & $1-3$ & 1.97 & 0.10 \\
\hline & 3 & midfielders & 4.78 & 0.38 & 0.17 & $1-4$ & 2.46 & 0.05 \\
\hline & 4 & forwards & 4.67 & 0.26 & 0.12 & $2-3$ & -0.21 & 0.84 \\
\hline & - & - & - & - & - & $2-4$ & 0.39 & 0.71 \\
\hline & - & - & - & - & - & $3-4$ & 0.49 & 0.64 \\
\hline \multirow{6}{*}{$\begin{array}{l}\text { Keeping the Ball on the Foot } \\
\text { (s) }\end{array}$} & 1 & goalkeepers & 5.86 & 1.41 & 0.82 & $1-2$ & 1.03 & 0.35 \\
\hline & 2 & defenders & 5.00 & 0.82 & 0.41 & $1-3$ & 1.27 & 0.25 \\
\hline & 3 & midfielders & 6.95 & 1.88 & 0.84 & $1-4$ & -0.35 & 0.74 \\
\hline & 4 & forwards & 6.14 & 0.82 & 0.37 & $2-3$ & -1.91 & 0.10 \\
\hline & - & - & - & - & - & $2-4$ & -2.06 & 0.08 \\
\hline & - & - & - & - & - & $3-4$ & 0.88 & 0.40 \\
\hline \multirow{6}{*}{ Ball juggling (quantity) } & 1 & goalkeepers & 25.33 & 5.51 & 3.18 & $1-2$ & -0.66 & 0.54 \\
\hline & 2 & defenders & 31.00 & 13.76 & 6.88 & $1-3$ & 1.32 & 0.23 \\
\hline & 3 & midfielders & 20.00 & 5.52 & 2.47 & $1-4$ & 0.32 & 0.76 \\
\hline & 4 & forwards & 23.60 & 8.20 & 3.67 & $2-3$ & 1.65 & 0.14 \\
\hline & - & - & - & - & - & $2-4$ & 1.01 & 0.35 \\
\hline & - & - & - & - & - & $3-4$ & -0.81 & 0.44 \\
\hline \multirow{6}{*}{ Keeping the Ball (s) } & 1 & goalkeepers & 13.63 & 0.45 & 0.26 & $1-2$ & 1.26 & 0.26 \\
\hline & 2 & defenders & 13.02 & 0.74 & 0.37 & $1-3$ & -0.49 & 0.64 \\
\hline & 3 & midfielders & 13.89 & 0.82 & 0.37 & $1-4$ & -0.52 & 0.62 \\
\hline & 4 & forwards & 13.78 & 0.36 & 0.16 & $2-3$ & -1.65 & 0.14 \\
\hline & - & - & - & - & - & $2-4$ & -2.05 & 0.08 \\
\hline & - & - & - & - & - & $3-4$ & 0.27 & 0.79 \\
\hline \multirow{6}{*}{ Running 60 m (s) } & 1 & goalkeepers & 9.85 & 0.29 & 0.17 & $1-2$ & 0.89 & 0.42 \\
\hline & 2 & defenders & 9.67 & 0.27 & 0.13 & $1-3$ & 1.37 & 0.22 \\
\hline & 3 & midfielders & 9.62 & 0.19 & 0.09 & $1-4$ & 0.96 & 0.38 \\
\hline & 4 & forwards & 9.55 & 0.49 & 0.22 & $2-3$ & 0.27 & 0.80 \\
\hline & - & - & - & - & - & $2-4$ & 0.42 & 0.69 \\
\hline & - & - & - & - & - & $3-4$ & 0.31 & 0.76 \\
\hline \multirow{6}{*}{ Shots on goal (balls) } & 1 & goalkeepers & 6.60 & 3.61 & 2.08 & $1-2$ & 0.26 & 0.80 \\
\hline & 2 & defenders & 6.50 & 1.29 & 0.65 & $1-3$ & 0.17 & 0.87 \\
\hline & 3 & midfielders & 6.60 & 3.13 & 1.40 & $1-4$ & 0.20 & 0.85 \\
\hline & 4 & forwards & 7.00 & 2.07 & 0.93 & $2-3$ & -0.06 & 0.95 \\
\hline & - & - & - & - & - & $2-4$ & -0.08 & 0.94 \\
\hline & - & - & - & - & - & $3-4$ & 0.00 & 1.00 \\
\hline \multirow{6}{*}{ Ball strikes for range $(\mathrm{m})$} & 1 & goalkeepers & 27.00 & 1.73 & 1.00 & $1-2$ & 1.46 & 0.20 \\
\hline & 2 & defenders & 25.50 & 1.00 & 0.50 & $1-3$ & 2.30 & 0.06 \\
\hline & 3 & midfielders & 23.20 & 2.49 & 1.11 & $1-4$ & 4.13 & 0.01 \\
\hline & 4 & forwards & 21.60 & 1.82 & 0.81 & $2-3$ & 1.72 & 0.13 \\
\hline & - & - & - & - & - & $2-4$ & 3.82 & 0.01 \\
\hline & - & - & - & - & - & $3-4$ & 1.16 & 0.28 \\
\hline
\end{tabular}


The average body weight of goalkeepers 12 years is $43.67 \mathrm{~kg}$, of defenders 12 years is $42 \mathrm{~kg}$, of midfielders 12 years is $43.8 \mathrm{~kg}$, of forwards 12 years is $44.6 \mathrm{~kg}$. The average body weight of goalkeepers 15 years is $55.43 \mathrm{~kg}$, of defenders 15 years is 52.25 $\mathrm{kg}$, of midfielders 15 years is $54.4 \mathrm{~kg}$, of forwards 15 years is $53.4 \mathrm{~kg}$. The findings differ somewhat from the results of studies by other authors [1], who found that goalkeepers have the greatest weight and body length. These differences with the results of other authors can be explained by the low football experience of the surveyed children and the need to improve the system of distribution of players by function.

Regarding the indicators of functional readiness, it can be noted that in terms of heart rate, the representatives of different game roles, both 12 and 15 years, do not have significant differences (Tables 1,2). But it should be noted that there is a tendency to the lowest values of resting heart rate at goalkeepers and increasing resting heart rate at

defenders, midfielders and the greatest values of resting heart at attackers.

The obtained data can be explained by the greater emotional endurance of the goalkeepers and the least by the attackers, which affects the resting heart rate. This trend is more pronounced in football players 15 years old compared to football players 12 years old. The average resting heart rate at goalkeepers 12 years is 76 beats $\cdot \mathrm{min}^{-1}$, for defenders 12 years is 76.5 beats $\cdot \mathrm{min}^{-1}$, for midfielders 12 years is 79.6 beats $\cdot \mathrm{min}^{-1}$, for forwards 12 years is 82.8 beats $\cdot \mathrm{min}^{-1}$. The average resting heart rate at goalkeepers 15 years is 68 beats $\cdot \mathrm{min}^{-1}$, at defenders 15 years is 72 beats $\cdot \mathrm{min}^{-1}$, at midfielders 15 years is 70.8 beats $\cdot \mathrm{min}^{-1}$, at forwards 15 years is 75.6 beats $\cdot \min ^{-1}$.

The average heart rate after shuttle running at goalkeepers 12 years is 178 beats $\cdot \mathrm{min}^{-1}$, at defenders 12 years is 177 beats $\mathrm{min}^{-1}$, at midfielders 12 years is 178.8 beats $\mathrm{min}^{-1}$, at forwards 12 years is 174 beats $\cdot \min ^{-1}$.

Table 2

Indicators of physical development, physical and technical readiness of football players of 15 years of different playing fields (goalkeepers, $n=7$, defenders, $n=15$, midfielders, $n=14$, forvards, $n=11$ )

\begin{tabular}{|c|c|c|c|c|c|c|c|c|}
\hline \multirow{2}{*}{$\frac{\text { Indexes }}{1}$} & \multicolumn{2}{|r|}{ Playing fields } & \multirow{2}{*}{$\frac{\bar{x}}{4}$} & \multirow{2}{*}{$\begin{array}{l}S \\
5\end{array}$} & \multirow{2}{*}{$\begin{array}{r}\mathrm{m} \\
6\end{array}$} & \multicolumn{2}{|c|}{$\mathrm{t}$} & \multirow{2}{*}{$\begin{array}{l}\mathrm{p} \\
9\end{array}$} \\
\hline & 2 & 3 & & & & 7 & 8 & \\
\hline \multirow{6}{*}{ Body length $(\mathrm{cm})$} & 1 & goalkeepers & 166.33 & 8.08 & 4.67 & $1-2$ & -1.61 & 0.17 \\
\hline & 2 & defenders & 172.75 & 1.26 & 0.63 & $1-3$ & -0.38 & 0.72 \\
\hline & 3 & midfielders & 168.20 & 6.10 & 2.73 & $1-4$ & -0.77 & 0.47 \\
\hline & 4 & forwards & 170.80 & 7.89 & 3.53 & $2-3$ & 1.45 & 0.19 \\
\hline & - & - & - & - & - & $2-4$ & 0.48 & 0.64 \\
\hline & - & - & - & - & - & $3-4$ & -0.58 & 0.58 \\
\hline \multirow{6}{*}{ Body weight (kg) } & 1 & goalkeepers & 55.00 & 6.25 & 3.61 & $1-2$ & 0.82 & 0.45 \\
\hline & 2 & defenders & 52.25 & 2.50 & 1.25 & $1-3$ & 0.11 & 0.92 \\
\hline & 3 & midfielders & 54.40 & 7.99 & 3.57 & $1-4$ & 0.49 & 0.64 \\
\hline & 4 & forwards & 53.40 & 3.21 & 1.44 & $2-3$ & -0.51 & 0.62 \\
\hline & - & - & - & - & - & $2-4$ & -0.59 & 0.58 \\
\hline & - & - & - & - & - & $3-4$ & 0.26 & 0.80 \\
\hline \multirow{6}{*}{ Heart rate rest (beats. $\mathrm{min}^{-1}$ ) } & 1 & goalkeepers & 68.00 & 3.46 & 2.00 & $1-2$ & -0.60 & 0.58 \\
\hline & 2 & defenders & 72.00 & 10.95 & 5.48 & $1-3$ & -0.84 & 0.43 \\
\hline & 3 & midfielders & 70.80 & 5.02 & 2.24 & $1-4$ & -1.23 & 0.26 \\
\hline & 4 & forwards & 75.60 & 10.04 & 4.49 & $2-3$ & 0.22 & 0.83 \\
\hline & - & - & - & - & - & $2-4$ & -0.51 & 0.62 \\
\hline & - & - & - & - & - & $3-4$ & -0.96 & 0.37 \\
\hline \multirow{6}{*}{$\begin{array}{l}\text { Heart rate after a shuttle } \\
\text { run (beats } \cdot \mathrm{min}^{-1} \text { ) }\end{array}$} & 1 & goalkeepers & 132.00 & 6.00 & 3.46 & $1-2$ & -1.97 & 0.11 \\
\hline & 2 & defenders & 142.50 & 7.55 & 3.77 & $1-3$ & -2.00 & 0.09 \\
\hline & 3 & midfielders & 151.20 & 15.53 & 6.95 & $1-4$ & -2.88 & 0.03 \\
\hline & 4 & forwards & 163.20 & 17.70 & 7.91 & $2-3$ & -1.02 & 0.34 \\
\hline & - & - & - & - & - & $2-4$ & -2.16 & 0.07 \\
\hline & - & - & - & - & - & $3-4$ & -1.14 & 0.29 \\
\hline \multirow{6}{*}{ Shuttle Run (s) } & 1 & goalkeepers & 24.24 & 0.17 & 0.10 & $1-2$ & 4.83 & 0.01 \\
\hline & 2 & defenders & 23.19 & 0.34 & 0.17 & $1-3$ & 2.63 & 0.04 \\
\hline & 3 & midfielders & 23.29 & 0.27 & 0.12 & $1-4$ & 4.17 & 0.01 \\
\hline & 4 & forwards & 23.46 & 0.29 & 0.13 & $2-3$ & -1.02 & 0.34 \\
\hline & - & - & - & - & - & $2-4$ & -1.28 & 0.24 \\
\hline & - & - & - & - & - & $3-4$ & -0.93 & 0.38 \\
\hline
\end{tabular}




\begin{tabular}{|c|c|c|c|c|c|c|c|c|}
\hline 1 & 2 & 3 & 4 & 5 & 6 & 7 & 8 & 9 \\
\hline \multirow{6}{*}{ Running 30 m (s) } & 1 & goalkeepers & 5.93 & 0.06 & 0.03 & $1-2$ & 2.39 & 0.06 \\
\hline & 2 & defenders & 5.49 & 0.31 & 0.16 & $1-3$ & 2.63 & 0.04 \\
\hline & 3 & midfielders & 5.41 & 0.33 & 0.15 & $1-4$ & 2.63 & 0.04 \\
\hline & 4 & forwards & 5.78 & 0.09 & 0.04 & $2-3$ & 0.35 & 0.73 \\
\hline & - & - & - & - & - & $2-4$ & -2.07 & 0.08 \\
\hline & - & - & - & - & - & $3-4$ & -2.45 & 0.04 \\
\hline \multirow{6}{*}{ Running 15 m (s) } & 1 & goalkeepers & 3.97 & 0.81 & 0.47 & $1-2$ & 1.28 & 0.26 \\
\hline & 2 & defenders & 3.41 & 0.34 & 0.17 & $1-3$ & 1.23 & 0.27 \\
\hline & 3 & midfielders & 3.54 & 0.15 & 0.07 & $1-4$ & 0.99 & 0.36 \\
\hline & 4 & forwards & 3.57 & 0.36 & 0.16 & $2-3$ & -0.76 & 0.47 \\
\hline & - & - & - & - & - & $2-4$ & -0.70 & 0.51 \\
\hline & - & - & - & - & - & $3-4$ & -0.21 & 0.84 \\
\hline \multirow{6}{*}{$\begin{array}{l}\text { Keeping the Ball on the } \\
\text { Foot (s) }\end{array}$} & 1 & goalkeepers & 7.04 & 2.65 & 1.53 & $1-2$ & -2.68 & 0.04 \\
\hline & 2 & defenders & 12.10 & 2.35 & 1.17 & $1-3$ & -0.26 & 0.81 \\
\hline & 3 & midfielders & 7.36 & 1.03 & 0.46 & $1-4$ & -0.57 & 0.59 \\
\hline & 4 & forwards & 8.27 & 3.10 & 1.39 & $2-3$ & 4.10 & 0.01 \\
\hline & - & - & - & - & - & $2-4$ & 2.04 & 0.08 \\
\hline & - & - & - & - & - & $3-4$ & -0.62 & 0.55 \\
\hline \multirow{6}{*}{ Ball juggling (quantity) } & 1 & goalkeepers & 35.33 & 6.81 & 3.93 & $1-2$ & -0.43 & 0.69 \\
\hline & 2 & defenders & 38.75 & 12.28 & 6.14 & $1-3$ & -1.25 & 0.26 \\
\hline & 3 & midfielders & 43.40 & 9.71 & 4.34 & $1-4$ & -2.52 & 0.05 \\
\hline & 4 & forwards & 46.40 & 5.59 & 2.50 & $2-3$ & -0.64 & 0.55 \\
\hline & - & - & - & - & - & $2-4$ & -1.26 & 0.25 \\
\hline & - & - & - & - & - & $3-4$ & -0.60 & 0.57 \\
\hline \multirow{6}{*}{ Keeping the Ball (s) } & 1 & goalkeepers & 9.77 & 0.25 & 0.15 & $1-2$ & -0.08 & 0.94 \\
\hline & 2 & defenders & 9.81 & 0.76 & 0.38 & $1-3$ & -0.08 & 0.94 \\
\hline & 3 & midfielders & 9.81 & 0.88 & 0.39 & $1-4$ & -0.01 & 0.99 \\
\hline & 4 & forwards & 9.06 & 0.24 & 0.11 & $2-3$ & -0.01 & 0.99 \\
\hline & - & - & - & - & - & $2-4$ & 2.08 & 0.08 \\
\hline & - & - & - & - & - & $3-4$ & 1.83 & 0.11 \\
\hline \multirow{6}{*}{ Running 60 m (s) } & 1 & goalkeepers & 8.65 & 0.08 & 0.04 & $1-2$ & -0.56 & 0.60 \\
\hline & 2 & defenders & 8.28 & 0.46 & 0.23 & $1-3$ & -2.62 & 0.04 \\
\hline & 3 & midfielders & 8.12 & 0.33 & 0.15 & $1-4$ & 3.91 & 0.01 \\
\hline & 4 & forwards & 8.16 & 0.15 & 0.07 & $2-3$ & -1.40 & 0.21 \\
\hline & - & - & - & - & - & $2-4$ & 0.54 & 0.61 \\
\hline & - & - & - & - & - & $3-4$ & 2.99 & 0.02 \\
\hline \multirow{6}{*}{ Shots on goal (balls) } & 1 & goalkeepers & 6.60 & 0.58 & 0.33 & $1-2$ & -0.19 & 0.85 \\
\hline & 2 & defenders & 9.00 & 3.59 & 1.80 & $1-3$ & 0.76 & 0.48 \\
\hline & 3 & midfielders & 10.33 & 2.92 & 1.30 & $1-4$ & 2.68 & 0.04 \\
\hline & 4 & forwards & 10.75 & 2.30 & 1.03 & $2-3$ & 0.81 & 0.45 \\
\hline & - & - & - & - & - & $2-4$ & 2.11 & 0.07 \\
\hline & - & - & - & - & - & $3-4$ & 1.45 & 0.19 \\
\hline \multirow{6}{*}{ Ball strikes for range $(\mathrm{m})$} & 1 & goalkeepers & 48.33 & 4.51 & 2.60 & $1-2$ & 2.39 & 0.06 \\
\hline & 2 & defenders & 41.00 & 3.65 & 1.83 & $1-3$ & 4.80 & 0.00 \\
\hline & 3 & midfielders & 37.00 & 2.35 & 1.05 & $1-4$ & 5.04 & 0.00 \\
\hline & 4 & forwards & 35.60 & 2.79 & 1.25 & $2-3$ & 2.00 & 0.09 \\
\hline & - & - & - & - & - & $2-4$ & 2.52 & 0.04 \\
\hline & - & - & - & - & - & $3-4$ & 0.86 & 0.42 \\
\hline
\end{tabular}

The average heart rate after shuttle running at goalkeepers 15 years is 132 beats $\cdot \min ^{-1}$, at defenders 15 years is 142.5 beats $\mathrm{min}^{-1}$, at midfielders 15 years is 151.2 beats $\cdot \mathrm{min}^{-1}$, at forwards 15 years is 163,2 beats $\min ^{-1}$. Differences between goalkeepers and forwards 15 years are significant at $\mathrm{p}<0.05$ (Tab. 1, 2). The findings can be explained by the fact that forwards are more emotionally reactive compared to the midfielders, defenders and goalkeepers, as well as the better shuttle performance in the attackers, midfielders and defenders compared to the goalkeepers.

Thus, the average value of shuttle running time for goalkeepers 12 years are $27.67 \mathrm{~s}$, for defenders 12 years is $27.35 \mathrm{~s}$, for midfielders 12 years is $27.46 \mathrm{~s}$, for forwards 12 years is $27.44 \mathrm{~s}$. The average time of shuttle running for goalkeepers 15 years is $24.24 \mathrm{~s}$, for defenders 15 years is $23.19 \mathrm{~s}$, for midfielders 15 years is $23.29 \mathrm{~s}$, for forwards 15 years is 23.46 s. Differences between goalkeepers and 
attackers 15 years old, goalkeepers and midfielders 15 years old, goalkeepers and defenders are significant at $\mathrm{p}<0.05$ (Tab. 1, 2).

A similar trend is observed in 15 meters running. Forwards, defenders and midfielders are better than goalkeepers. So, the average value of running for $15 \mathrm{~m}$ at goalkeepers 12 years is $5.06 \mathrm{~s}$, for defenders 12 years is $4.73 \mathrm{~s}$, for midfielders 12 years is $4.77 \mathrm{~s}$, for forwards 12 years is $27.44 \mathrm{~s}$. The average running distance of $15 \mathrm{~m}$ for goalkeepers of 15 years is 4.67 seconds, for defenders of 15 years is $3.97 \mathrm{~s}$, for midfielders 15 years is $3.4 \mathrm{~s}$, for forwards 15 years is $3.57 \mathrm{~s}$ (Tab. 1,2$)$.

A similar trend is observed in 30 meters running. Forwards, defenders and midfielders, these indicators are better than goalkeepers. Thus, the average values of running for $30 \mathrm{~m}$ at goalkeepers 12 years is $6.79 \mathrm{~s}$, for defenders 12 years is $6.49 \mathrm{~s}$, midfielders 12 years is $6.53 \mathrm{~s}$, forwards 12 years is $6.55 \mathrm{~s}$. The average running distance of $30 \mathrm{~m}$ for goalkeepers 15 years is $5.93 \mathrm{~s}$, for defenders 15 years is $5.48 \mathrm{~s}$, for midfielders 15 years is $5.4 \mathrm{~s}$, for forwards 15 years is $5.78 \mathrm{~s}$. Differences between goalkeepers and forwards 15 years, goalkeepers and midfielders 15 years, goalkeepers and defenders 15 years are significant at $p<0,05($ Tab. 1, 2).

The detected pattern is also observed in the indicators of running at $60 \mathrm{~m}$. Forwards, defenders and midfielders, these indicators are better than for goalkeepers. Thus, the average values of running at $60 \mathrm{~m}$ for goalkeepers 12 years is $9.85 \mathrm{~s}$, for defenders 12 years is $9.66 \mathrm{~s}$, for midfielders 12 years is $9.62 \mathrm{~s}$, for forwards 12 years is $9.55 \mathrm{~s}$. The average running distance of $60 \mathrm{~m}$ for goalkeepers 15 years is $8.64 \mathrm{~s}$, for defenders 15 years is $8.27 \mathrm{~s}$, for midfielders 15 years is $8.12 \mathrm{~s}$, for forwards 15 years is $8.16 \mathrm{~s}$. Differences between goalkeepers and forwards 15 years, goalkeepers and midfielders 15 years, goalkeepers and defenders 15 years are significant at $\mathrm{p}<0,05$ (Tab. 1, 2).

The biggest differences between the representatives of different game roles are found in the technical readiness, especially concerning the indicators of juggling, keeping the ball on the foot, accuracy of the range of strikes. The average goal time of a goalkeeper 12 years is $13.63 \mathrm{~s}$, for defenders 12 years is $13.01 \mathrm{~s}$, for midfielders 12 years is 13.88 $\mathrm{s}$, for forwards 12 years is $13.78 \mathrm{~s}$. Goalkeepers of 15 years have a median time at $9.77 \mathrm{~s}$, defenders - at 9.8 $\mathrm{s}$, midfielders - at $9.81 \mathrm{~s}$, forwards - at $9.06 \mathrm{~s}$. Differences between goalkeepers and forwards 15 years are significant at $p<0.05$ (Tab. 1, 2).
The average juggling value for goalkeepers 12 years is 25.3 times, for defenders 12 years is 31 times, for midfielders 12 years is 20 times, for forwards 12 years is 23.6 times. The average value of juggling for goalkeepers 15 years is 35.3 times, for defenders 15 years is 38.75 times, for midfielders 15 years is 43.4 times, for forwards 15 years is 46.4 times. Differences between goalkeepers and forwards 15 years are significant at $\mathrm{p}<0.05$ (Tab. 1, 2).

Mean goalkeeping time for goalkeepers 12 years is $5.86 \mathrm{~s}$, for defenders 12 years is $5.00 \mathrm{~s}$, for midfielders 12 years is $6.94 \mathrm{~s}$, for forwards 12 years is $6.13 \mathrm{~s}$. Differences between midfielders and forwards 12 years and quarterbacks and midfielders 12 years are significant at $p<0.05$ (Tab.1, 2). Mean goalkeeping time for goalkeepers of 15 years is 7.03 $\mathrm{s}$, for defenders 15 years is $12.09 \mathrm{~s}$, for midfielders 15 years is $7.36 \mathrm{~s}$, for forwards 15 years is $8.26 \mathrm{~s}$. Differences between all representatives of different gaming specializations of 15 years were significant at $\mathrm{p}<0.05$ (Tab. 1, 2).

The average values of the accuracy of shots of the ball on goal at goalkeepers 12 years make 6,6 points, at defenders 12 years make 5 points, at midfielders 12 years make 6,6 points, at forwards 12 years make 7 points. The average values of the accuracy of shots of the ball on goal at goalkeepers 15 years make 6,6 points, at defenders 15 years make 9 points, at midfielders 15 years make 10,3 points, at forwards make 15 years 10,75 points. Differences between goalkeepers and forwards 15 years are significant at $\mathrm{p}<0.05$ (Tab.1, 2).

The average value of the ball strikes at goalkeepers 12 years is $27 \mathrm{~m}$, at defenders 12 years is $25.5 \mathrm{~m}$, at midfielders 12 years is $23.2 \mathrm{~m}$, at forwards 12 years is $21.6 \mathrm{~m}$, at goalkeepers 15 years is $48.3 \mathrm{~m}$, at defenders 15 years is $41.25 \mathrm{~m}$, at midfielders 15 years is $37 \mathrm{~m}$, at forwards 15 years is $35.6 \mathrm{~m}$. Forwards and midfielders for 15 years are significant at $\mathrm{p}<0.05$ (Tab.1, 2).

Thus, the field players at speed capabilities are significantly superior to goalkeepers. Goalkeepers, by contrast, have lower running speeds (Fig. 1).

The level of speed endurance is relatively high for defenders and midfielders, as opposed to goalkeepers. The obtained data allowed us to build models of physical development, physical and technical readiness of players of 12 and 15 years of different game roles, on the basis of which training programs for representatives of different game roles can be developed (Fig. 1). 

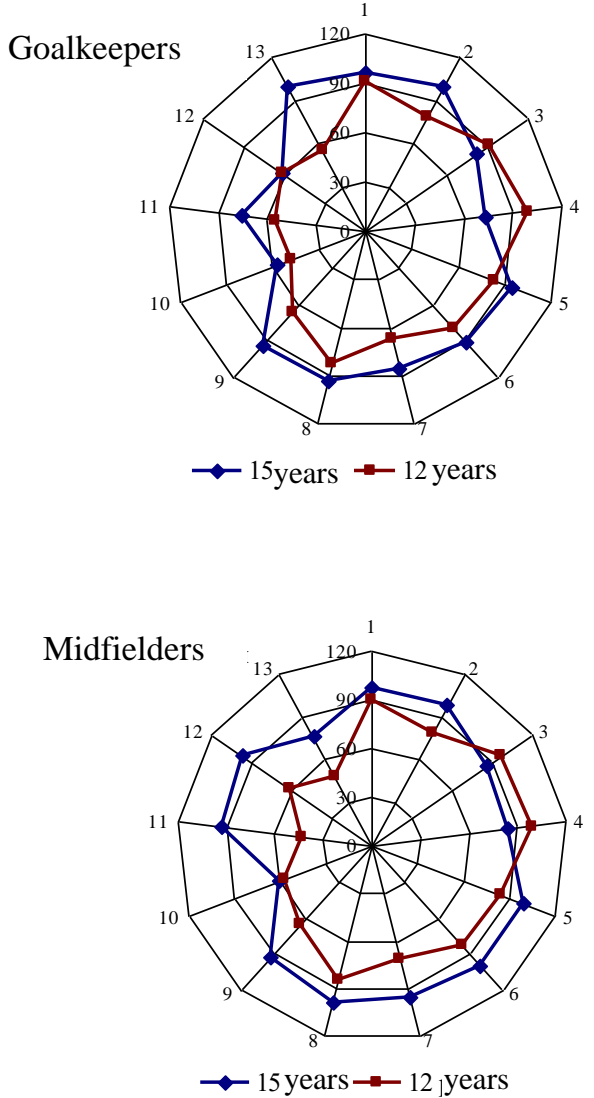

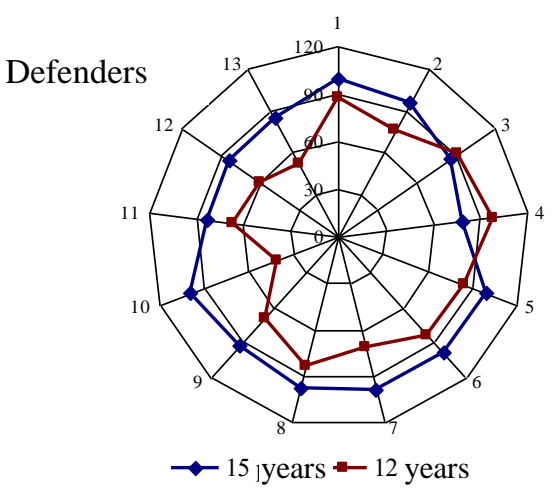

Forwards

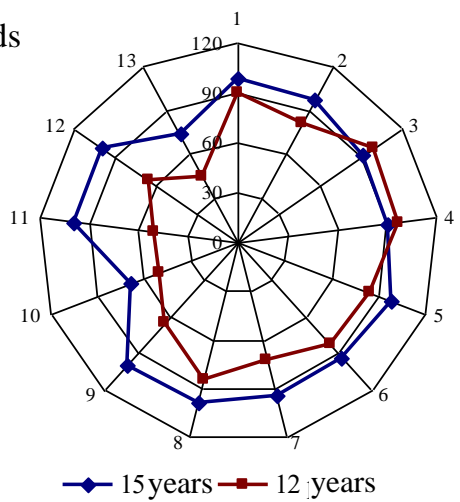

Fig. 1. Basic models of physical development, physical and technical readiness of players of 12 and 15 years of different playing roles:

1 - Body length (cm); 2 - Body weight $(\mathrm{kg}) ; 3$ - resting heart rate (beats $\left.\cdot \mathrm{min}^{-1}\right) ; 4$ - heart rate after a shuttle run (beats $\mathrm{min}^{-1}$ ); 5 - Shack running (s); 6 - Running $30 \mathrm{~m}$ (s); 7 - Run $15 \mathrm{~m}$ (s); 8 - Keeping the ball on the foot (s); 9 - Ball juggling (quantity); 10 - Ball management (s); 11 - Running 60 m (s);

12 - Shots on goal (balls); 13 - Ball strikes (m)

\section{Discussion}

The study confirmed the hypothesis of the presence of significant differences in the indicators of physical development, the level of physical and technical readiness of young players of different playing fields. These discrepancies are already observed at the age of 12 years and are exacerbated at the age of 15 years. The data obtained indicate the need for a differentiated approach to the training of young players of age groups.

As is well known, modern youth football develops by increasing the requirements to all sides of the training of young athletes $[1,6,7]$. In the process of competitive activity on the body are significant in magnitude and duration of loading, requiring the maximum mobilization of the body of young athletes and make high demands on their readiness. Therefore, for the proper construction of the training process, it is necessary to identify the features of the physical and technical readiness of the players of different game roles $[9,17]$.

The results of our study complement the results of the authors $[1,19]$ who believe that in the preparation of football players of this age the coach should take into account their morpho-functional capabilities $[4,6]$. Comparing the indicators of physical development of football players, it can be seen that in these parameters the players of different playing roles are practically no different from each other. The findings differ somewhat from the results of studies by other authors [21], who found that goalkeepers have the greatest weight and body length. These differences with the results of other authors can be explained by the low football experience of the surveyed children and the need to improve the system of distribution of players by function.

In football, as in other sports games, each game position poses certain requirements to the level of manifestation of different qualities and properties of athletes, which must be taken into account in their evaluation $[4,5]$. Therefore, in our study, we compared players of different game roles with each other. Goalkeepers have been found to have virtually low technical and physical fitness scores in virtually all testing results, as opposed to hitters, defenders, and midfielders. We explain this by the fact that the goalkeeper is a highly specialized player of defense and trains on a separate program. As a result of comparing most indicators of physical and technical preparedness of the strikers, defenders and 
midfielders, no significant differences were found. This is due to the fact that in the training process the coach often changes the playing role of young athletes, in order to train and find the optimal playing role of each football player, depending on the competitive period. After all, the main feature of adolescence is associated with the process of puberty, resulting in significant changes in the psyche, there is high emotionality, mood imbalance, inflammation, exaggeration of their capabilities. Very often the manifestation of the so-called sense of adulthood is reflected in the behavior of the players in the game. At the same time, the body of adolescents is quickly adjusted to work and easily readjusted to another type of activity, due to the great mobility of nervous processes [19]. Therefore, in the practical work of the coach actively put players of 12 and 15 years in different zones of the playing field, thereby teaching them the specifics of different playing roles.

Thus, when choosing training loads for goalkeepers, trainers need to take into account the data obtained, which will allow to develop optimal programs for the development of flexibility, speed, strength, agility, as well as for improving technical skill. When selecting funds in the training process of representatives of other game roles, it is necessary to pay special attention to the implementation of the techniques of football players 12 and 15 years.

\section{Conclusions}

1. Young players of 12 and 15 years of different game specializations differ in terms of physical and technical fitness. The largest number of

\section{References}

1. Sobko IM, Kozina ZhL, Andruhiv VM, Seryi AV, Ayaz Ahmad. Model characteristics of physical development, physical and technical preparedness of football players 15 years of different roles. Health, sport, rehabilitation, 2018; 4(2): 106-114. doi:10.34142/HSR.2018.04.02.10

2. Gastin PB, Tangalos C, Torres L, Robertson S. Match running performance and skill execution improves with age but not the number of disposals in young Australian footballers. Journal of Sports Sciences, 2017;35(24):2397-2404.

3. Pizarro AP, Dominguez AM, Serrano JS, GarciaGonzalez L, Alvarez FD. Effects of a comprehensive teaching program on dribbling and passing decisionmaking and execution skills of young footballers. Kinesiology, 2017;49(1):74-83.

4. Kozina Z. Factor models of the physical preparedness of volleyball players of a high class of various game role. Pedagogy, Psychology and medical and biological problems of physical education and sport, 2007;9: 80-85.

5. Kozina ZL, Ol'khovyj OM, Temchenko VA. Influence of information technologies on technical fitness of students in sport-oriented physical education. Physical education of students, 2016;1:21-28. http://dx.doi.org/10.15561/20755279.2016.0103 significant differences were found in the technical readiness of football players for 15 years.

2. Field players at speed capabilities are significantly superior to goalkeepers. Goalkeepers, on the contrary, have lower running speeds. The level of speed endurance is relatively high for defenders and midfielders, as opposed to goalkeepers. The obtained data allowed us to build models of physical development, physical and technical readiness of players of 12 and 15 years of different playing fields, on the basis of which training programs for representatives of different playing roles can be developed.

3. The data obtained indicate the need for a differentiated approach in the training process of young football players, taking into account their playing role. The differentiated approach is more relevant at the age of 15 compared to the age of 12 .

\section{Acknowledgements}

The study was conducted in accordance with the research work of Ministry of Education and Science of Ukraine for 2019-2020 «Theoretical and methodological foundations of technology development for the restoration of musculoskeletal system and functional state and prevention of injuries and representatives of different age groups in physical culture and sports» (№ 0119U100634).

\section{Conflict of interest}

The authors state no conflict of interest.

6. Varley I, Hughes DC, Greeves JP. Increased training volume improves bone density and cortical area in adolescent football players. International journal of sports medicine, 2017, 38(5):341-346.

7. Campos E, Pereira R, Alves I, Mineiro AS, Scorcine C, Madureira F. Physical and behavioral analysis of young athletes practicing field football, during different training designs [in Portuguese]. Rev Bras Futsal Futebol. 2017;9(32):16-20.

8. Polevoy G. The development of the ability to equilibrium football players 10-11 years with different nervous system. Pak J Med Health Sci. 2018;12(1):496-499.

9. Aksoy Y, Agaoglu SA. The comparison of sprint reaction time and anaerobic power of young football players, volleyball players and wrestlers. Kinesiol Slov. 2017;23(2):5-14.

10. Figueira B, Gonçalves B, Masiulis N, Sampaio J. Exploring how playing football with different age groups affects tactical behaviour and physical performance. Biol Sport. 2018;35(2):145-153; doi: 10.5114/biolsport.2018.71603.

11. Arrieta P, Castellano J, Guridi I, Echeazarra I. Effects of a program based on small-sided games on the physical condition in young football players [in Spanish]. Rev Int Cienc Deporte. 2017;13(50):370 380; doi: 10.5232/ricyde2017.05004

12. Bolotin A, Bakayev V. Pedagogical conditions necessary for effective speed-strength training of 
young football players (15-17 years old). J Hum Sport Exerc. 2017;12(2):405-413; doi: 10.14198/jhse.2017.122.17.

13. Jaafar Z, Kee J, Abdul Hadi H, Ahmad Tajuddin NA. Anthropometrical and fitness level changes following a 12-week walking football program for obese primary school children aged 8-11. Med Sport. 2018;71(3):451-460; doi: $10.23736 / \mathrm{s} 0025$ 7826.18.03285-4.

14. Pons RA, Villacampa SF, Canada AP. Anthropometric profile characterization of youth players from the Angolan Football Academy [in Portuguese]. Rev Bras Futsal Futebol. 2018;10(37):138-149.

15. Da Silva IM, Palma A, Ramos SP, Galvão PVM, Simão R, Costa e Silva G, et al. Somatotypological analysis in football athletes with age between nine and twenty years: a transversal study [in Portuguese]. Rev Bras Futsal Futebol. 2019;11(42):111-118.

16. Grabara M. Analysis of body posture between young football players and their untrained peers. Hum Mov. 2012;13(2):120-126; doi: 10.2478/v10038-012-00127.

17. Neogi A, Chakraborty C, Chatterjee S, Dey SK. Anthropometric profiles and pulmonary function parameters of male football \& hockey players according to their specific playing position: a comparative study. Int $J$ Appl Exerc Physiol. 2018;7(3):10-23; doi: 10.30472/ijaep.v7i3.233.

18. Clemente FM, Nikolaidis PT, Linden CMI, Silva B. Effects of small-sided soccer games on internal and external load and lower limb power: a pilot study in collegiate players. Hum Mov. 2017;18(1):50-57; doi: 10.1515/humo-2017-0007.

19. Jaworska L, Hawrylak A, Burzyński B, SzczepańskaGieracha J. Effect of progressive muscle relaxation on pain threshold and effectiveness of footballers' training. Hum Mov. 2015;16(4):225-228; doi: 10.1515/humo-2015-0043.

20. Chromik K, Burdukiewicz A, Pietraszewska J, Stachoń A, Wolański P, Goliński D. Characteristics of anteroposterior curvatures of the spine in soccer and futsal players. Hum Mov. 2017;18(4):49-54; doi: 10.1515/humo-2017-0039.

21. Gonçalves E, Gonzaga AS, Cardoso FSL, Teoldo I. Anticipation in soccer: a systematic review. Hum Mov. 2015;16(2):91-101; doi: 10.1515/humo-2015-0032.

\section{Інформація про авторів}

\section{Kozina Zh.L.}

http://orcid.org/0000-0001-5588-4825

zhanneta.kozina@gmail.com

H. S. Skovoroda Kharkiv National Pedagogical

University

Alchevskyh str. 29, Kharkov, 61002, Ukraine

\section{Leemans A.}

http://orcid.org/0000-0002-9306-6126

\section{A.Leemans@umcutrecht.nl}

University Medical Center Utrecht, the Netherlands

UMC Utrecht, Heidelberglaan 100, 3584 CX Utrecht

\section{Marino J.}

julian.marino.davolos@gmail.com

University del Chubut, Argentina

Lewis Jones 248, U9103 Rawson, Chubut, Argentina

\section{Cruz J.}

juancruzarias11@gmail.com

University del Chubut, Argentina

Lewis Jones 248, U9103 Rawson, Chubut, Argentina

\section{Golenkov A.A.}

zhanneta.kozina@gmail.com

H. S. Skovoroda Kharkiv National Pedagogical

University

Alchevskyh str. 29, Kharkov, 61002, Ukraine

\section{Dubich V.V.}

zhanneta.kozina@gmail.com

H. S. Skovoroda Kharkiv National Pedagogical

University

Alchevskyh str. 29, Kharkov, 61002, Ukraine

Принята в редакцию 12.06.2019

\section{Козіна Ж.Л.}

http://orcid.org/0000-0001-5588-4825

zhanneta.kozina@gmail.com

Харківський національний педагогічний університет імені Г.С. Сковороди

вул.Алчевських 29, Харків, 61002, Україна

\section{Ліманс А.}

http://orcid.org/0000-0002-9306-6126

A.Leemans@umcutrecht.nl

Медичнийий центр Університету в Уріхті, Нідерланди УМС Утрехт, Нідерланли 100, 3584 СХ Утрехт

\section{Марино Ю.}

julian.marino.davolos@gmail.com

Університет в Чубуті, Аргентина

Левис Джонс, 248, U9103, Равсон, Чубут, Аргентина

\section{Круз X.}

juancruzarias11@gmail.com

Університет в Чубуті, Аргентина

Левис Джонс, 248, U9103, Равсон, Чубут, Аргентина

\section{Голенков А.А.}

zhanneta.kozina@gmail.com

Харківський національний педагогічний університет імені Г.С. Сковороди

вул.Алчевських 29, Харків, 61002, Україна

\section{Дубич В.В.}

zhanneta.kozina@gmail.com

Харківський національний педагогічний університет імені Г.С. Сковороди

вул.Алчевських 29, Харків, 61002, Україна 